\title{
A NEW YELLOW-FLOWERED CHILOSCHISTA (ORCHIDACEAE: AERIDINAE) FROM THAILAND
}

\author{
STIG DAlströM ${ }^{1,2,3,6} \&$ Marta KolanowsKa ${ }^{4,5}$ \\ ${ }^{1} 2304$ Ringling Boulevard, unit 119, Sarasota FL 34237, USA \\ ${ }^{2}$ Lankester Botanical Garden, University of Costa Rica, Cartago, Costa Rica \\ ${ }^{3}$ National Biodiversity Centre, Serbithang, Bhutan \\ ${ }^{4}$ Department of Geobotany and Plant Ecology, Faculty of Biology and Environmental Protection, \\ University of Lodz, UL. Sienkiewicsa 55/4, 90-009 Lodz, Poland \\ ${ }^{5}$ Global Change Research Centre AS CR, Belidla 986/4a, 60300, Brno, Czech Republic \\ ${ }^{6}$ Corresponding author: stigdalstrom@gmail.com
}

\begin{abstract}
A new species of Chiloschista Lindl. from western Thailand is described and illustrated with a line drawing and photographs. It is compared with the sympatric $C$. parishii Seidenf., from which it differs in having larger flowers, which are 11-12 $\mathrm{mm}$ across versus $8-10 \mathrm{~mm}$ across for $C$. parishii. The new species also distinctly differs in having widely spreading rostellum lobes and a viscidium that is as broad as the length of the stipe, as opposed to downward directed rostellum lobes and a viscidium that is distinctly narrower than the length of the stipe for $C$. parishii. The same distinguishing features separate the new species from the similarly colored $C$. trudelii Seidenf., which has inward-directed rostellum lobes and a viscidium that is distinctly narrower than the length of the stipe.
\end{abstract}

KEY Words: Epidendroideae, new Chiloschista, Thailand orchid flora, Vandeae

Introduction. The orchid genus Chiloschista Lindl. was first described by John Lindley, who proposed to segregate Epidendrum usneoides D.Don from Nepal into a separate taxon (Lindley 1832). Over the years, almost 30 specific epithets were applied to Chiloschista, but currently about 10 (Chen \& Wood 2009, Wood 2014), or 22 (Govaerts 2020) species are accepted, distributed from the Indian subcontinent through SE Asia to Australia. The most recent phylogenetic analysis conducted by Zou et al. (2015) using five DNA markers (ITS, $m a t \mathrm{~K}$, trnL-F, $p s b \mathrm{~A}-t r n \mathrm{H}$, and atpI-H) revealed that Chiloschista is a monophyletic taxon related to the group composed of the Phalaenopsis clade, Thrixspermum clade, and Vanda clade of Aeridinae. In previous treatments, Chiloschista was classified in Sarcochilinae (Schlechter 1926), Aeridinae (Dressler 1993), or Phalaenopsidinae (Szlachetko 2003). Representatives of this genus are monopodial plants growing as epiphytic or lithophytic herbs. Plants usually appear only as a cluster of roots, which hide the distinctly abbreviated stem. Narrowly elliptic and acute leaves only appear during the rainy season and soon fall off at the arrival of the dry season. The roots are gray, green, brownish or purple, photosynthetic, flat to terete, and sometimes scabrid. Chiloschista plants produce ephemeral flowers with a more or less clawed lip, which is attached to the apex of the column foot and is 3-lobed, deeply saccate/ pouched, or spurred (Wood 2014).

In May of 2009, an unknown Chiloschista was discovered growing epiphytically on Hevea brasiliensis (rubber tree) in western Thailand (Fig. 1). Because of its vulnerable position due to ongoing destructive human activities, a plant was collected and introduced to cultivation where it flowered in April the following year. The flowers superficially resemble the sympatric C. parishii Seidenf., but differ in being larger and of a warm yellow color, with only faint brown spots on the basal half of the sepals and petals (Fig. 2), while the smaller C. parishii generally has distinct spots throughout the sepals and petals (Fig. 3; Seidenfaden 1988). A more careful examination and comparison of the column details reveal more distinct differences where the unknown species has widely spreading rostellum lobes and a distinctly broadened viscidium (Fig. 4, 8), in comparison with C. parishii, which has downward projected and more or less parallel rostellum lobes and 


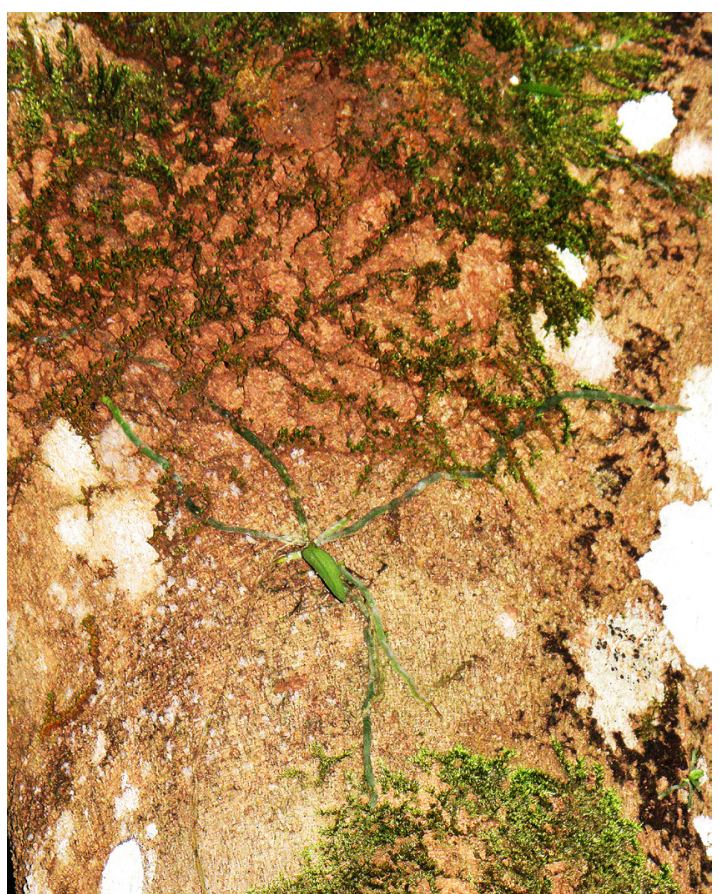

FIGURE 1. Chiloschista lindstroemii growing epiphytically on a rubber tree (Hevea brasiliensis). Photo by Stig Dalström.

a distinctly narrower viscidium (Fig. 5, 8). The widely spreading rostellum lobes and the broadened viscidium also distinguish the unknown species from the colorwise similar C. trudelii Seidenf., (Fig. 6) which has inward projecting rostellum lobes and a narrower viscidium (Fig. 7-8). The rather distinct difference in size between the unknown species described here and C. parishii is most easily observed when the various flower parts are placed next to each other on the same scale (Fig. 8). We have found no other Chiloschista species that color-wise or morphologically corresponds with the unknown species and we, therefore, conclude that it is new to science and is described here.

\section{TAXONOMIC TREATMENT}

Chiloschista lindstroemii Dalström \& Kolan., sp. nov. TYPE: Thailand. Kanchanaburi Province: collected in May 2009, flowered in cultivation 29 April, 2010, A. Lindström 09-1571 (holotype: BK). (Fig. 2, 4, 8).

Diagnosis: Chiloschista lindstroemii is superficially similar to the sympatric $C$. parishii, but differs in having larger flowers, $c a$. $11-12 \mathrm{~mm}$ across with widely

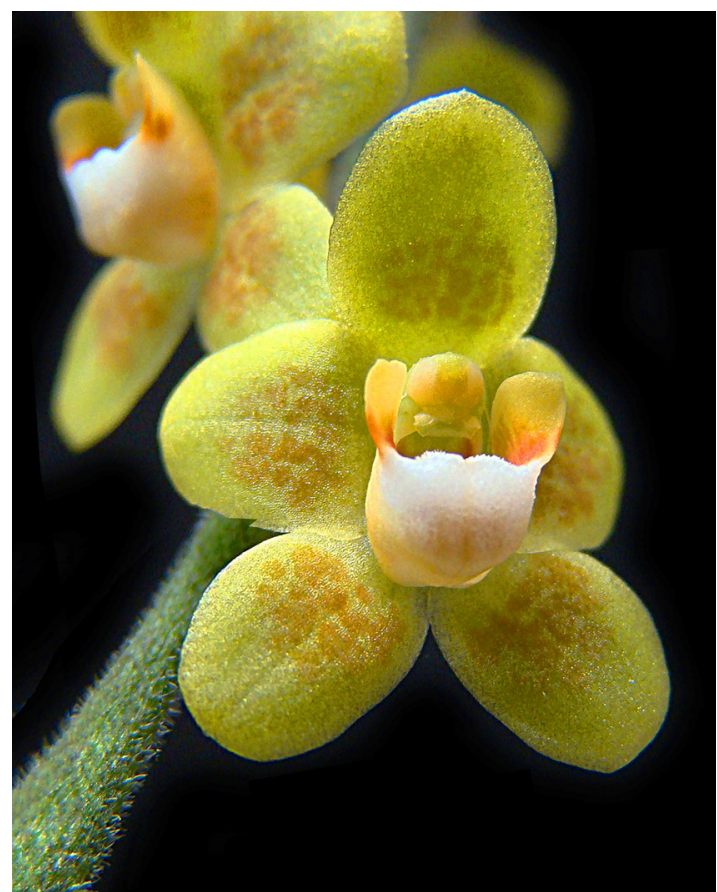

FIGURE 2. Chiloschista lindstroemii has an attractive flower in a warm yellow color, faintly spotted with brown. Photo by Stig Dalström.

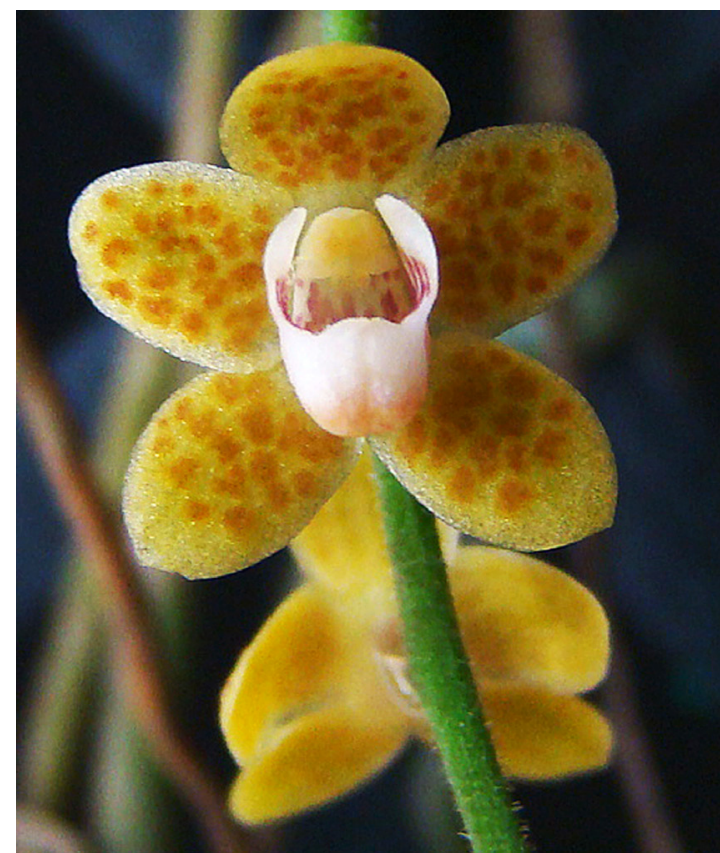

FiguRe 3. Chiloschista parishii is sympatric with $C$. lindstroemii, but differs by having smaller flowers with differently shaped lip callus and rostellum lobes. Photo by Stig Dalström. 

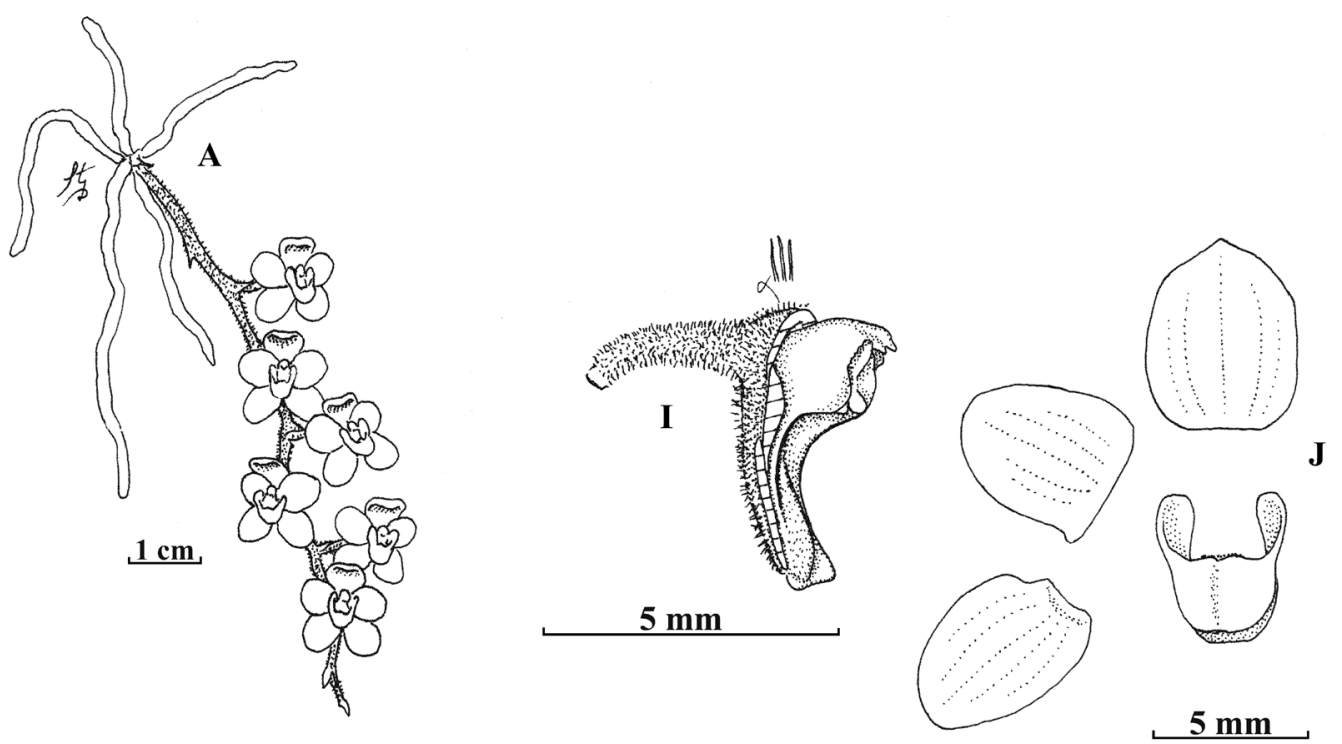

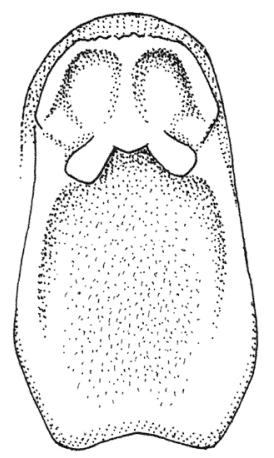

C

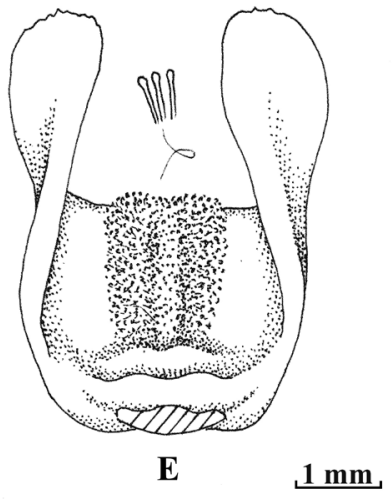

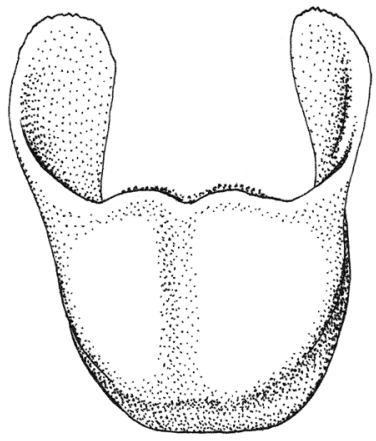

D

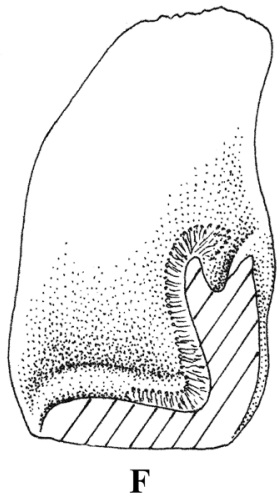

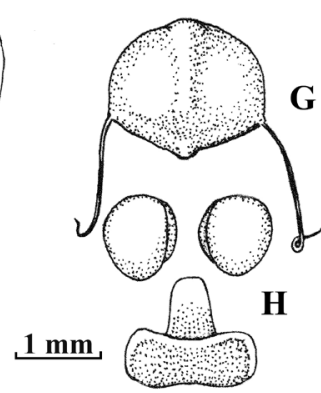

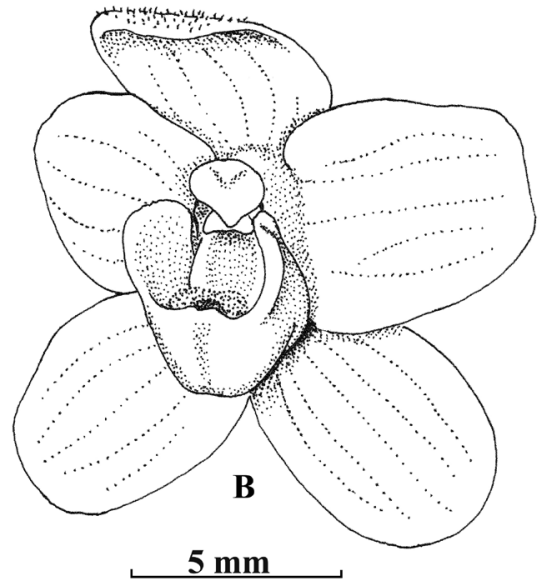

Figure 4. Chiloschista lindstroemii Dalström \& Kolan. A. Plant habit. B. Flower angled front view. C. Column front view displaying the spreading rostellum lobes. D. Lip front view. E. Lip interior view. F. Lip split, interior lateral view. G. Anther cap dorsal view. H. Pollinarium with pollinia and stipe with viscidium. I. Column lateral view. J. Flower dissected. Drawn from the holotype by Stig Dalström. 

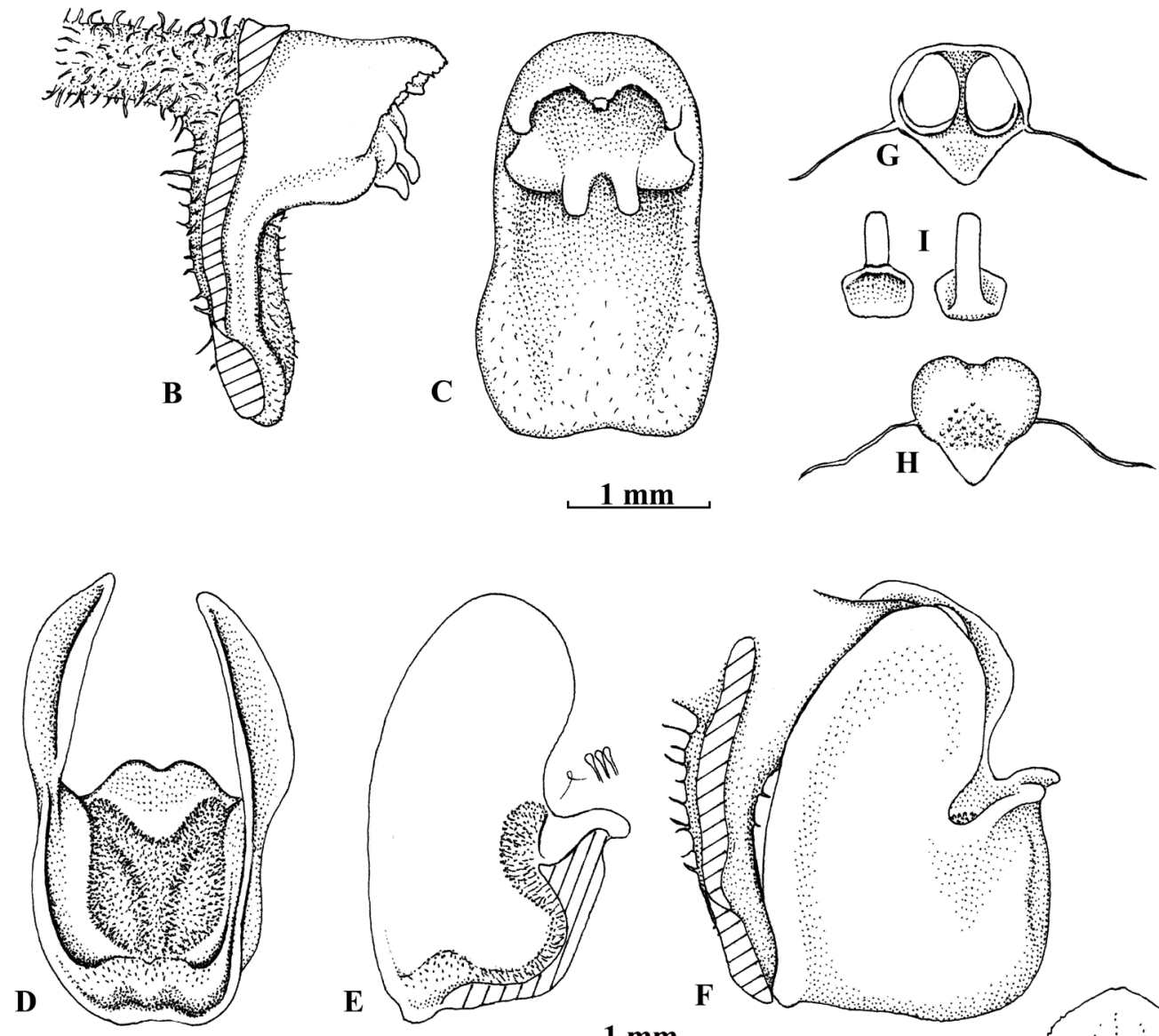

E
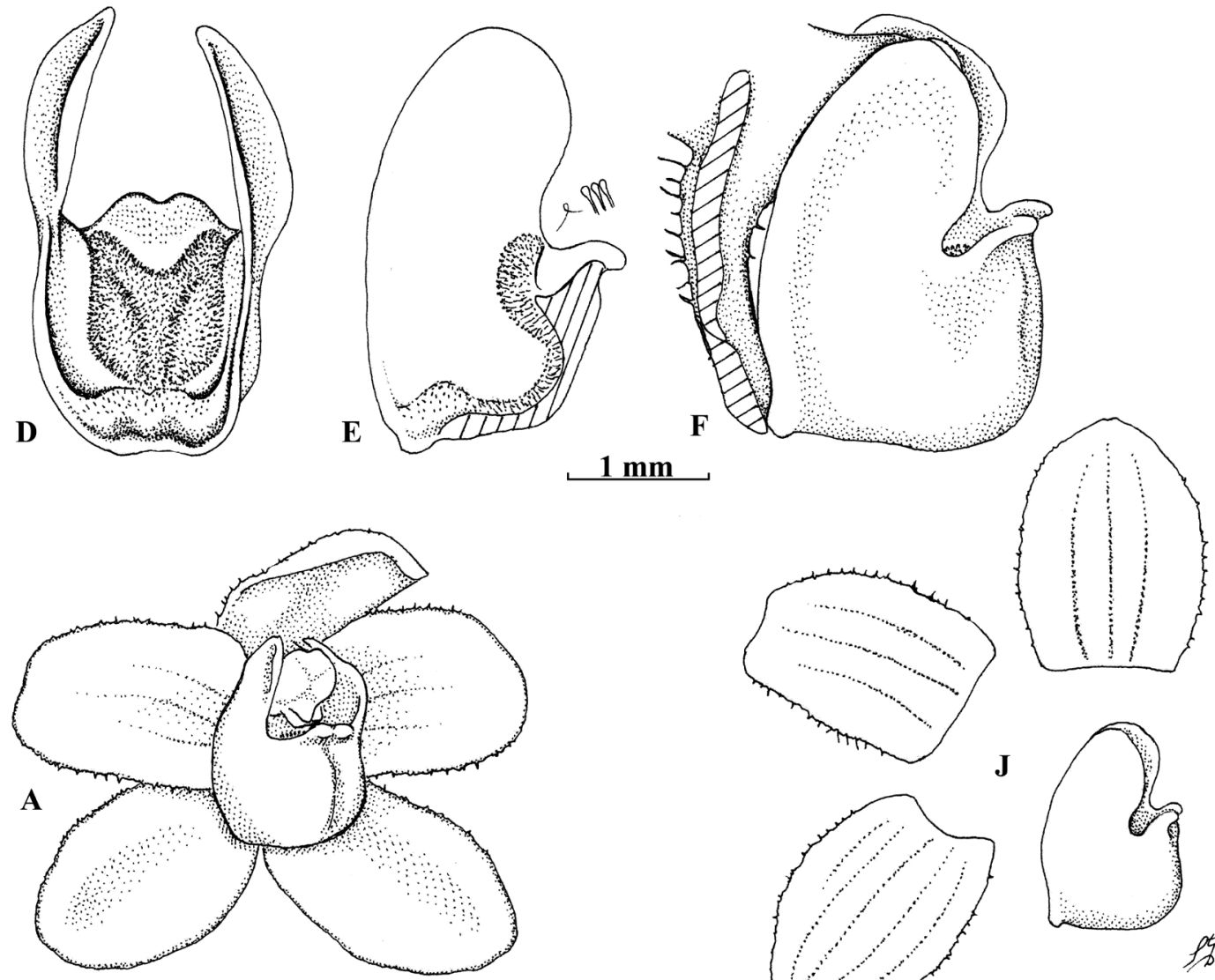

$5 \mathrm{~mm}$
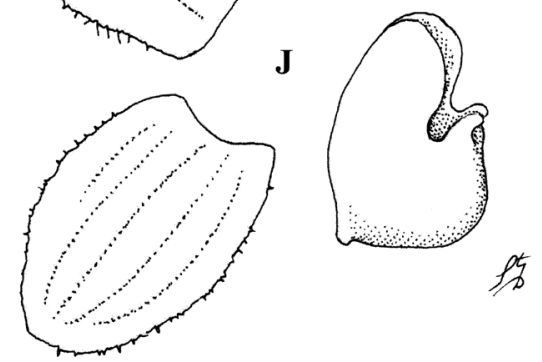

FiguRE 5. Chiloschista parishii Seidenf. A. Flower angled front view. B. column lateral view. C. Column front view displaying downward directed rostellum lobes. D. Lip interior back view. E. Lip cleft, lateral view. F. Column and lip lateral view. G. Anther cap with pollinia ventral view. H. Anther cap dorsal view. I. Stipe and viscidium back and front view. J. Dissected flower. Drawn from S. Dalström 3023 (Dalström archives) by Stig Dalström. 


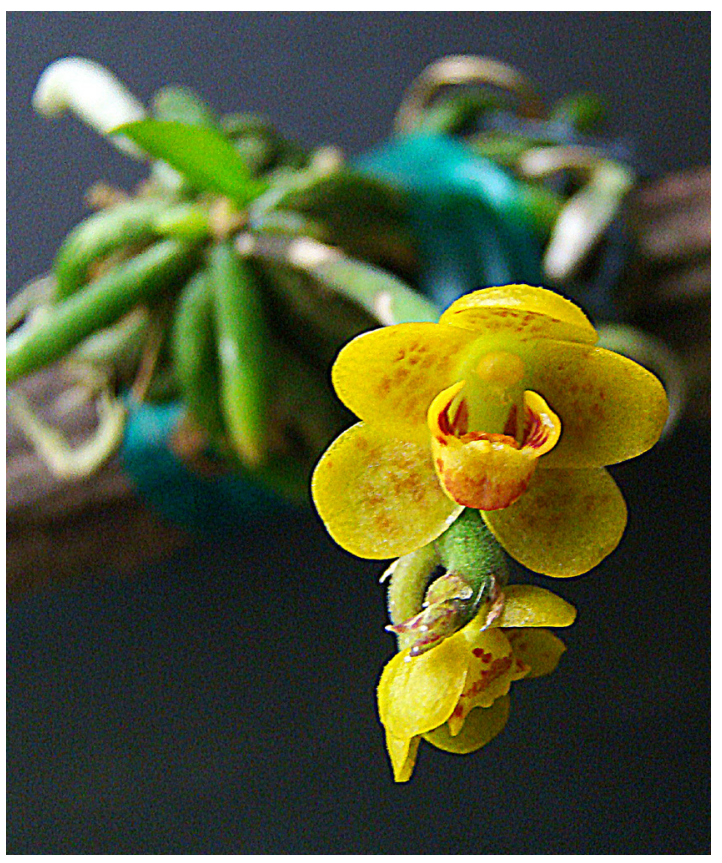

FiguRE 6. Chiloschista trudelii is superficially similar to $C$. lindstroemii, but differs primarily in the shape of the rostellum lobes. Photo by Stig Dalström.

spreading rostellum lobes and a viscidium that is as broad as the length of the stipe, as opposed to downward directed and parallel rostellum lobes and a viscidium that is distinctly narrower than the length of the stipe for C. parishii. The new species also differs from the rather similar $C$. trudelii which has inward-directed rostellum lobes and a viscidium that is distinctly narrower than the length of the stipe.

Herb epiphytic. Roots numerous, spreading, terete to slightly flattened, 2-3 mm thick. Stem minute, ca. 0.5-1.0 mm long. Leaves one or two, deciduous during the rainless season, conduplicate, ovate and acute (roots, stem and leaf not preserved on the type specimen). Inflorescence more or less pendent, $c a .7 \mathrm{~cm}$ long with seven flowers on the type specimen (but old inflorescences observed in the wild reveal that it can be at least twice as long with many more flowers), almost straight to somewhat flexuous, finely pubescent, laxly racemose; stem and floral bracts scale-like, narrowly acute, dorsally pubescent, 3-4 mm long. Pedicel with ovary finely pubescent, 3-4 mm long. Flower with rather flat and spreading lateral sepals and petals, 11-12 $\mathrm{mm}$ across; dorsal sepal light yellow with pale brown spots on the basal half, externally finely pubescent, internally glabrous, broadly elliptic, entire, apically indistinctly obtuse, $6 \times 5 \mathrm{~mm}$; lateral sepals similar in color and pubescence, fused basally along the column foot, indistinctly obliquely ovate, entire, apically indistinctly obtuse to rounded, $6 \times 4 \mathrm{~mm}$; petals similar in color, glabrous, sessile and fused to the column foot, with a minute angle near the lower base, then almost linear to indistinctly obovate, entire, apically rounded, $5.0 \times 4.5 \mathrm{~mm}$; lip basally dark yellow with yellow lateral lobes streaked with red, and a white frontal part, rigidly attached to the column foot, deeply saccate and indistinctly canaliculated ventrally, 3-lobed, lateral lobes erect to slightly incurved, apically somewhat falcate and finely denticulate, median lobe short and fleshy, indistinctly 2-lobulate, ca. $5 \mathrm{~mm}$ high and 4.0$4.5 \mathrm{~mm}$ wide; callus in form of fleshy, broad, finely puberulent swelling, extending from the base and up to the median lobe where it creates a distinct pit, or cavity, leaving the apex of the lip glabrous; column very short and stocky, $1.5-2.0 \mathrm{~mm}$ long, including the anther cap and with a $2.8-3.0 \mathrm{~mm}$ long column foot, with spreading rostellum lobes; anther cap light yellow, galeate with a pair of filiform tendrils, $c a .2 \mathrm{~mm}$ long, on each side; pollinarium of a pair of obliquely globose and indistinctly flattened, cleft pollinia on a $c a$. $1.5 \mathrm{~mm}$ long, narrowly rectangular to trapezoid stipe on a broadly rectangular and indistinctly constricted viscidium, $c a$. $1.5 \mathrm{~mm}$ broad.

Distribution: Chiloschista lindstroemii is currently known only from the type location in western Thailand. The exact locality of this species is withheld from the public in order to protect it from being eradicated by commercial collectors. Specific locality information for scientific treatments can be obtained from the authors upon request.

Eponymy: Named in honor of Anders Lindström (Fig. 9), a world leading authority in Cycadaceae and many other tropical plant families. He works at Nong Nooch Tropical Garden, Thailand.

AcKNOwLEDGMENTS. The authors would like to thank Kampon Tansacha, the owner of Nong Nooch Tropical Garden for his generous support and administrative assistance. We also thank Anders Lindström for superb field assistance, the Sarasota Orchid Society for financial support, and Wesley Higgins for improving the manuscript. 


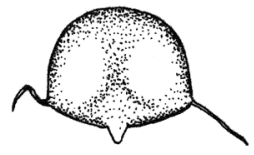

G
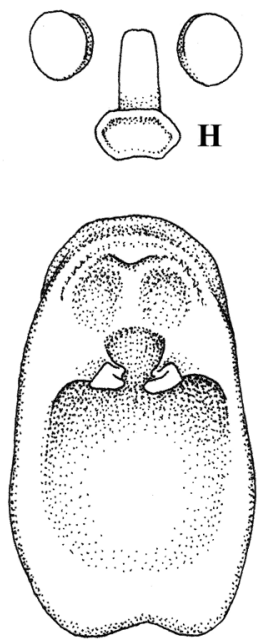

D
$5 \mathrm{~mm}$

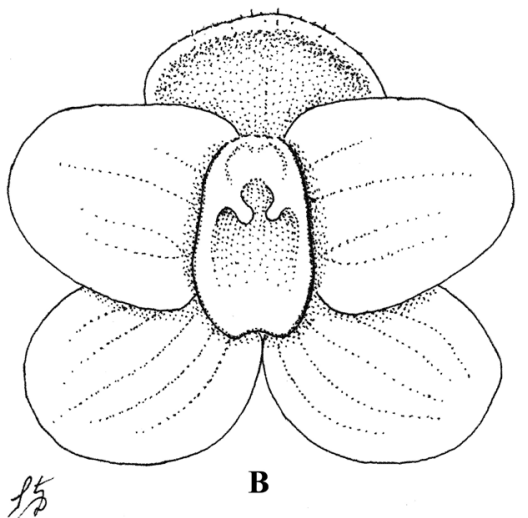

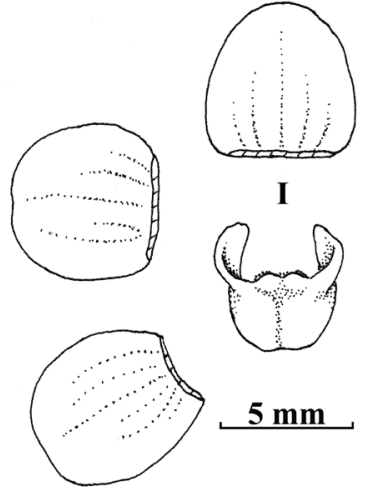

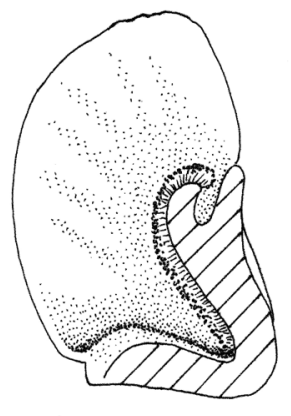

$\mathbf{E}$

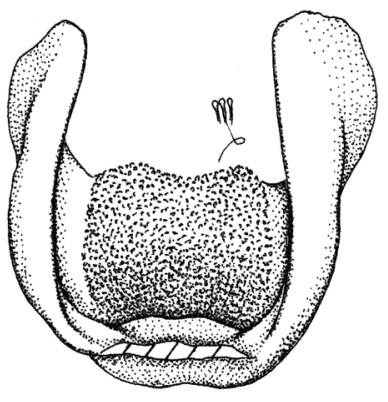

$\mathbf{F}$
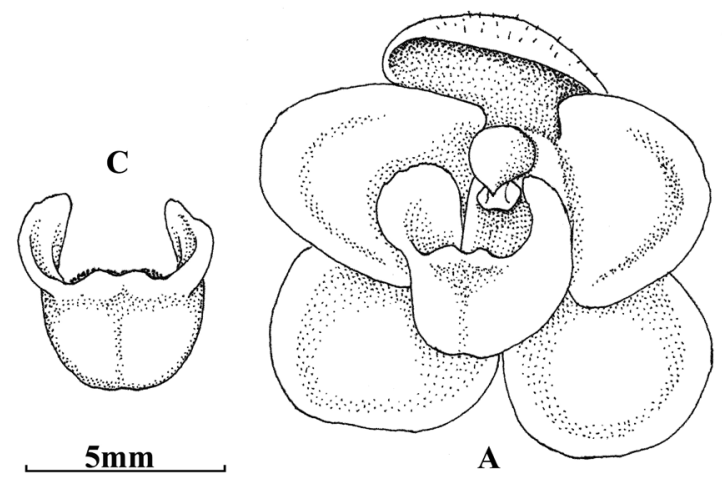

A

Figure 7. Chiloschista trudelii Seidenf. A. Flower angled front view. B. Flower front view with lip removed. C. Lip front view. D. Column front view. E. Lip split and interior lateral view. F. Lip interior back view. G. Anther cap dorsal view. H. Pollinarium, with pollinia and stipe with viscidium. I. Flower dissected. Drawn from S. Dalström 3017 (Dalström archives) by Stig Dalström.

Right, Figure 8. A. Chiloschista lindstroemii. A1. Column frontal view. A2. Lip lateral view. A3. Lip split with interior view. A4. Flower dissected. Drawn from the holotype by Stig Dalström. B. Chiloschista parishii. B1. Column frontal view. B2. Lip lateral view. B3. Lip split with interior view. B4. Flower dissected (with lip lateral view). Drawn from S. Dalström 3023 (Dalström archives) by Stig Dalström. C. Chiloschista trudelii. C1. Column frontal view. C2. Lip lateral view. C3. Lip split with interior view. C4. Flower dissected. Drawn from S. Dalström 3017 (Dalström archives) by Stig Dalström. 


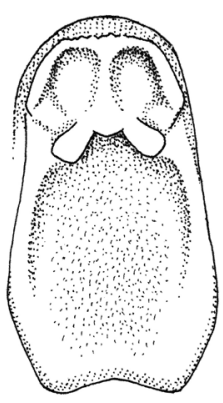

A1

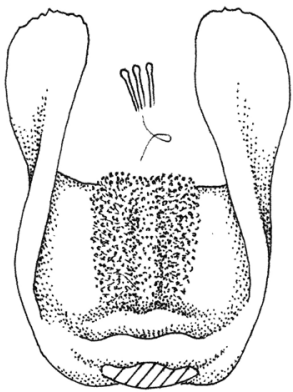

A2

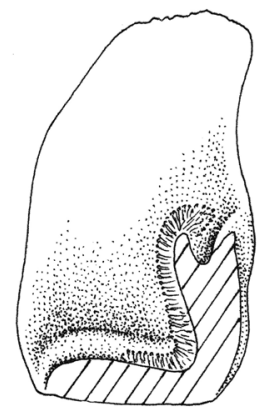

A3

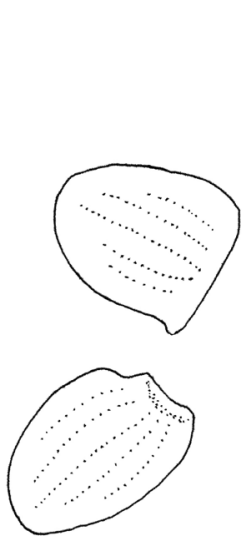

A4

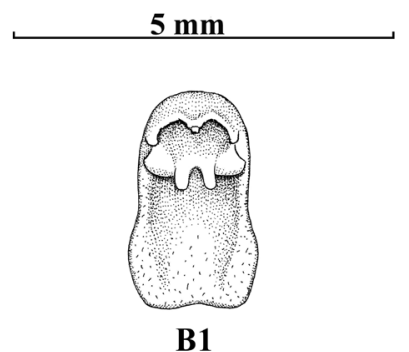

B1

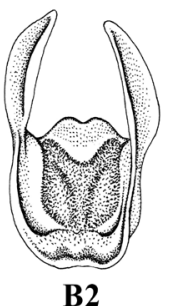

$5 \mathrm{~mm}$

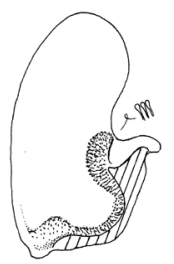

B3

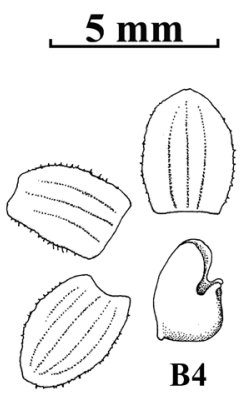

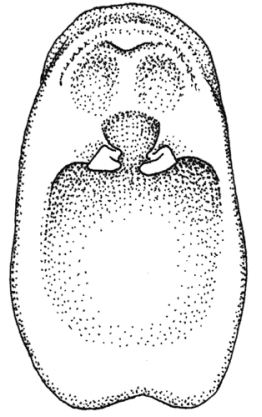

C1

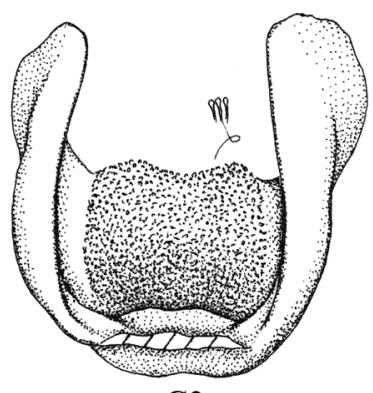

C2

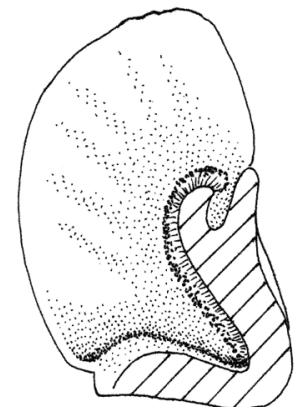

C3

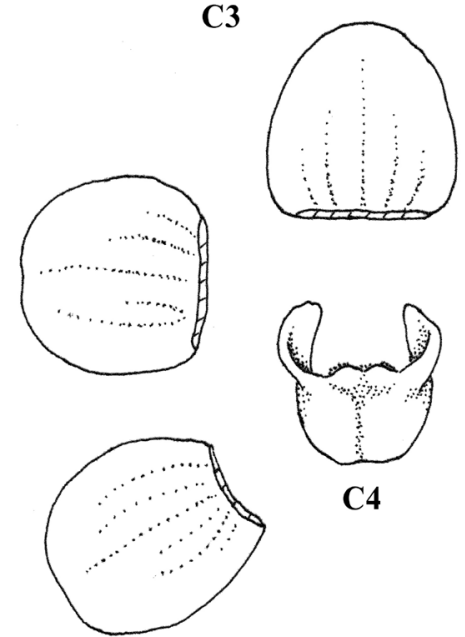

掎 


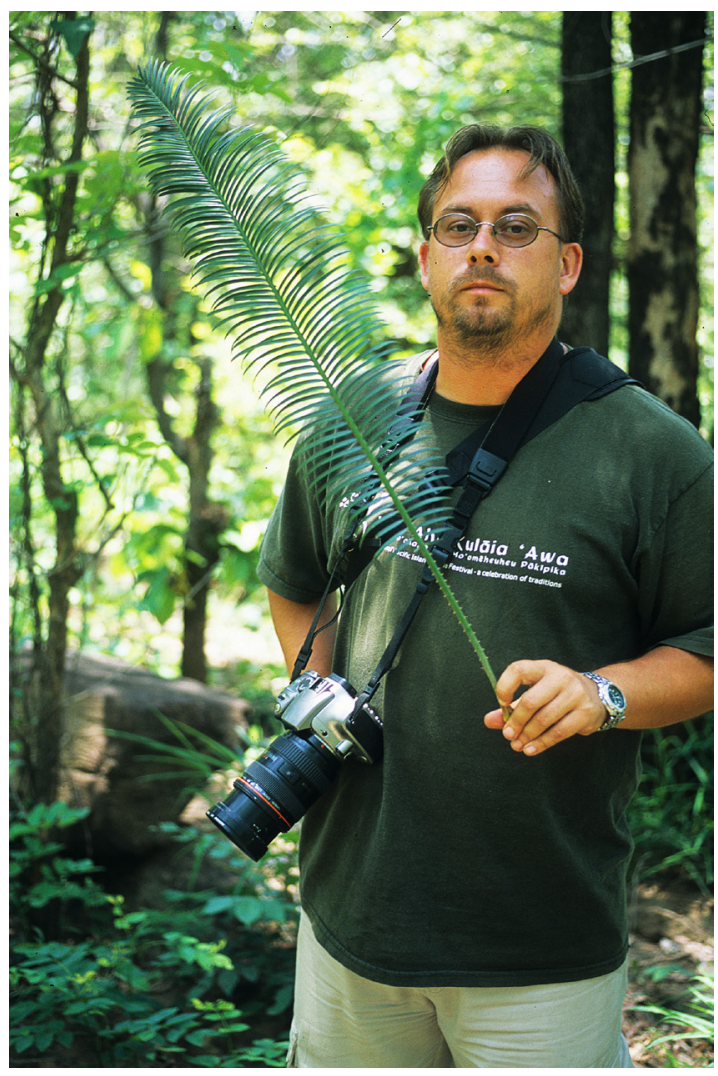

Figure 9. Anders Lindström, the Nong Nooch Tropical Garden's world leading taxonomic and horticultural expert on Cycadaceae and many other tropical plant groups. Photo by Stig Dalström.

\section{LITERATURE CITED}

Chen, X. \& J. Wood. (2009). Orchidaceae. In: C. Y. Wu, P. H. Raven \& D. Y. Hong (eds.), Flora of China, volume 25 (pp. 470-471). St. Louis: Science Press, Beijing, \& Missouri Botanical Garden Press.

Dressler, R. L. (1993). Phylogeny and classification of the orchid family. Portland: Dioscorides Press.

Govaerts, R. (2020). Chiloschista. World Checklist of Selected Plant Families. Royal Botanic Gardens, Kew. UK. Retrieved from http://wcsp.science.kew.org [accessed July 23, 2020].

Lindley, J. (1832). Chiloschista. Edwards's Botanical Register, 18, t.1522.

Schlechter, R. (1926). Das system der orchidaceen. Notizblatt des königl. botanischen gartens und museums zu Berlin, 9, 563-591.

Szlachetko, D. L. (2003). Gynostemia Orchidalium III. Orchidaceae - Vandoideae (Polystachyeae, Cymbidieae, Cataseteae, Thecosteleae, Vandeae). Acta botanica Fennica, 176, 1-311.

Seidenfaden, G. (1988). Chiloschista Lindl. Orchid Genera in Thailand 14. Fifty-nine vandoid Genera. Opera botanica, 95, 168-181.

Wood, J. (2014). Chiloschista. In: A. M. Pridgeon, P. J. Cribb, M. W. Chase \& F.N. Rasmussen (eds.), Genera Orchidacearum, Volume 6, Epidendroideae (Part 3) (pp. 152-156). Oxford: Oxford University Press.

Zou, L. H., Huang, J. X., Zhang, G. Q., Liu, Z. J. \& Zhuang, X. Y. (2015). A molecular phylogeny of Aeridinae (Orchidaceae: Epidendroideae) inferred from multiple nuclear and chloroplast regions. Molecular phylogenetics and evolution, 85, 247-254. 